\section{Patterns of Culture}

By Ruth Benedict. Pp. xiii +291. (London: George Routledge and Sons, Ltd., 1935.) 10s. $6 d$. net.

Dr. Ruth Benedict, in a stimulating and at times provocative book, has imported the theory of relativity into the study of social anthropology, which she, like some others, regards as the whole of anthropology. She argues that in the study of cultures, European spectacles and European standards must be abandoned, and the elements of any given culture under inspection evaluated exclusively in the terms of the culture to which they belong. How this works out in actual practice is demonstrated by a study of three strongly contrasted cultures, that of the Zuñi Indians of New Mexico, of the natives of Dobu in Melanesia and the Kwakiutl of Vancouver Island. In the case of each, she shows the characteristic reaction produced by analogous circumstances in contrasting social conditions.

In demonstrating her theories, Dr. Benedict shows much originality and freshness of outlook. Her general position, however, in its stress on the relativity of cultural elements, does not in the long run get much beyond what the now much criticised 'evolutionary' anthropologist meant when he insisted upon sympathetic understanding in the study of the culture of backward peoples when construed in terms of their environments, even though he may have erred, according to the modern view, in regarding that environment as representing a stage in the development of culture.

\section{The Struggle for Existence}

By G. F. Gause. Pp. ix +163 . (Baltimore, Md. : The Williams and Wilkins Co.; London: Baillière, Tindall and Cox, 1934.) 13s. $6 d$.

THERE is no doubt as to the interest of biologists in all questions relating to populations and the struggle for existence. The author attacks these both as an expert mathematician and as a biologist, which his work shows to be a necessary combination. In animals, the processes in the struggle are much more complicated than in plants, where certain principles seem likely to be enunciated within a few years. Population growth requires to be studied together with its limiting factors, and this is further developed in chapters relating to the competitions both between species of yeasts and between species of Paramecium. Then follows a study of two species one of which devours the other, the chain here being Bacteria $\rightarrow$ Paramecium $\rightarrow$ Didinium. In Nature there can be no constancy of conditions; perpetual interferences, proved to be often due to immigrations, allowing no constancy of results.

Such investigations give ideas and stimulate that spirit of inquiry that rightly appeals so strongly to the younger biologists of to-day. The price (13s.6d.) is too high for the ready sale that this book deserves; the American price is 3.00 dollars, so that this is only the fair exchange rate, whereas scientific books published in England are often priced at 50 per cent more than the exchange justifies in the States, a difference that kills their sale.
Through my Telescope: Astronomy for All By W. T. Hay. Pp. xiii +128 . (London: John Murray, 1935.) 3s. 6d. net.

THIs book, as its title suggests, is chiefly concerned with observational astronomy, although a sufficient background of astronomical facts is included to enable an intelligent interest to be taken in the objects observed. There is, in fact, a surprising amount of information compressed into its small space. The main theme, however, is the pleasure to be derived from, and the scientific value of, systematic observation of heavenly bodies with moderate instrumental equipment. The illustrations are from drawings by the author, and the plates give excellent ideas as to what one may expect to see in a mediumsized telescope-being far better for this purpose than photographs, which frequently give rise to disappointment at the telescope. The final chapter gives hints as to the use of telescopes, and the whole book should be an encouragement to many to follow the author's example in becoming regular astronomical observers.

Wandlungen in den Grundlagen der Naturwissenschaft: Zwei Vorträge

Von Werner Heisenberg. Pp. 45. (Leipzig: S. Hirzel, 1935.) n.p.

THE separate publication of these two lectures, which appeared in different periodicals in 1933 and 1934, directs the attention of a wider circle of readers to the views of one of the leading physicists of the day on natural knowledge. It is not without pride that Heisenberg reviews the field already conquered by modern physics. But in all humility he does not think that these conquests have brought us any nearer to the understanding of reality, because of the mathematical character adopted by natural philosophy. Pure speculation, on the other hand, can no longer claim attention if it ignores the formal results of scientific investigation. At present, the way to know Nature should be left for everyone to find individually, unless we wish to hope that the future will provide us with a single method satisfying all points of view.

T. G.

\section{British Industries and their Organization}

By Prof. G. C. Allen. Second edition. Pp. xi +338 . (London, New York and Toronto : Longmans, Green and Co., Ltd., 1935.) 10s. 6d. net.

IN the second edition of this most readable book (cf. Nature, 133, 153; 1934) Prof. Allen extends his stocktaking of the major industries of Great Britain and their organisation to cover the years of the depression up to 1933. The statistical tables and bibliography have been brought up to date and the discussion of the far-reaching changes in economic policy during the last five years as well as of the course of Government action in the coal, the iron and steel and the cotton industries con. siderably enhance the value of the book to those who seek a broad view of these most important problems. 